\title{
Effects of enzyme supplementation on the digestion of low glucosinolate rapeseed meal in vitro, and its utilization by broiler chicks
}

\author{
Ourida Alloui, Malgorzata Chibowska \\ and Stefania Smulikowska
}

\author{
The Kielanowski Institute of Animal Physiology and Nutrition, \\ Polish Academy of Sciences \\ 05-110 Jablonna near Warsaw, Poland
}

(Received 23 February 1994; accepted 12 May 1994)

\begin{abstract}
The effect of 6 commercial enzyme preparations, degrading mainly the non-starch polysaccharides, on the nutritional value of low-glucosinolate rapeseed meal (RSM) was evaluated in vitro and in vivo. Solubility of protein, ADF and NDF in RSM incubated with or without the addition of $1 \%$ of enzyme was measured in vitro. The protein and amino acid digestibility and metabolizable energy of RSM was determined on 4-wecks old broilcr cockerels in a balance experiment, while growth performance was evaluated for 3 weeks in 8 -day old cockerels fed diets containing $35 \%$ of RSM unsupplemented or supplemented with $0,1 \%$ of enzyme.

In vitro protein solubility was increased by Bio-feed Pro and Fnergex and solubility of NDF and ADF by Energex only after $10 \mathrm{~h}$ incubation. None of the preparations improved significantly the protein and amino acids digestibility nor $\mathrm{AME}_{\mathrm{N}}$ value in the balance experiment but significant changes in apparent digestibility of NDF and ADF were found.

No statistically significant effects of enzymes on chicken performance were noted, however chicks fed the diet with Bio-feed Plus were the heaviest and better utilized feed, while those fed with Bio-feed Pro had lower feed utilization.
\end{abstract}

KEY WORDS: rapeseed meal, enzymes, dietary fibre, metabolizable energy, broiler chicks

\section{INTRODUCTION}

Low glucosinolate rapeseed meal (RSM) is a valuable component of feeds for poultry, because it contains from 35 to $40 \%$ crude protein of a good amino acid composition. The amount of carbohydrates which can be utilized by poultry as 
a source of energy, however, is small, because of low content of starch and sugars, 4 and $8 \%$, respectively.

Non-starchy polysaccharides (NSP), called also dietary fibre, reach up to $35 \%$ of RSM. The main components of RSM NSP are cellulose, hemicellulose, pentosans, pectins, $\beta$-glucans and gums, which are made up of xylose, arabinose, glucose, galactose, rhamnose, mannose and galacturonic acid, and are combined into large and complex molecules. NSP and lignin are strongly bound to mineral and nitrogen complexes (Theander and Aman, 1977). Rapc seed dietary fibre lowers protein digestion and stimulates bacterial fermentation in the digestive tract of rats (Bjergegaard et al., 1991). It is digested to a very small extent by chicks, since the birds are not equipped in appropriate digestive enzymes, so the metabolizable energy of RSM for chicks is low and varies between 6 and $8 \mathrm{MJ} / \mathrm{kg}$ of DM. One of the methods for increasing the energy value of RSM may be its supplementation with enzyme preparations that can degrade dietary fibre into easily absorbable sugars.

The objective of this study was to examine whether preparations, recommended for diets containing soya bean meal and cereals, and containing enzymes degrading NSP, may improve the digestion of dietary fibre of RSM, and its utilization by chicks.

\section{MATERIAL AND METHODS}

\section{Material}

The study was conducted using commercial low-glucosinolate rapeseed meal (RSM) containing (in \% DM): crude protein 35.6; fat 6.2; ash 7.3; nitrogen-free extractives 36.3; crude fibre 14.6; NDF 31.3; ADF 22.1; $\Lambda \mathrm{ME}_{\mathrm{N}}$ (calculated according to the equation given in WPSA Tables, 1986) $8.58 \mathrm{MJ} / \mathrm{kg}$ of DM.

The following enzyme preparations produced by Novo-Nordisk were used: Energex ( $\beta$-glucanase, hemicellulase, pectinase), Bio-feed Plus (hemicellulase, $\beta$-glucanase, cellulase, cellobiase, xylanase), Bio-feed $\mathrm{Mg}$ (the same as Bio-feed Plus but with added $\alpha$-amylase and pentosanase), Bio-feed Pro (endoproteinases), Alpha-Gal (invertase, $\alpha$-galactase), Bio-feed Alpha ( $\alpha$-amylase, $\beta$-glucanase).

\section{In vitro test}

RSM with or without the addition of $1 \%$ Energex, Bio-feed Plus, Bio-feed Mg or Bio-feed Pro, was mixed in proportion $1: 10$ with $0.1 \mathrm{M}$ sodium acetate buffer $(\mathrm{pH} 5.2)$, and incubated at $39^{\circ} \mathrm{C}$ for 3,5 or $10 \mathrm{~h}$. The mixtures were then centrifuged and nitrogen content in supernatants was determined. 
In samples incubated with the first three preparations for 5 and $10 \mathrm{~h}$ the NDF and ADF content was also determined.

\section{Experiments on chickens}

Experiment 1 was conducted on 70, 28-day-old Astra B cockerels with the average body weight about $860 \mathrm{~g}$, by modified Sibbald (1986) method. RSM, alone, or mixed with the $0,3 \%$ of Bio-feed Mg, Bio-feed Plus, Energex, Bio-feed Pro or Bio-feed Pro and Bio-feed Plus preparations was moistened, cold pelleted, and dried at $45^{\circ} \mathrm{C}$ for $5 \mathrm{~h}$.

The chicks were housed in individual balance cages equipped for the quantitive collection of excreta in a controlled environment with $24 \mathrm{~h} \mathrm{light} / \mathrm{d}$. Ten birds constituted an experimental group. The cockerels were fasted for $30 \mathrm{~h}$, then offered $50 \mathrm{~g}$ of pelleted RSM. After $1 \mathrm{~h}$ the left-overs were weighted, and for the next $36 \mathrm{~h}$ the excreta were quantitatively collected. During the same time the excreta of 10 non-fed chicks were also collected. The samples were lyophilized and the content of DM was determined. Excreta of two randomly chosen birds were pulled according to the DM content and the total N, ADF, NDF and gross energy content measured. In pooled excreta samples from each group, the total and urinary $\mathrm{N}$ and the amino acid content were determined.

The apparent digestibility of DM, protein, amino acids, ADF and NDF was calculated, as well as the true $\left(\mathrm{TME}_{\mathrm{i}}\right)$ and apparent $\left(\mathrm{AME}_{\mathrm{N}}\right)$ metabolizable encrgy of RSM according to Sibbald (1986).

Experiment 2 was conducted on 196, 8-day-old Astra B cockerels with the initial weight of $110 \mathrm{~g}$. The birds were housed in pairs in cages equipped with heaters and feed and water supply, one group consisted of 14 pairs of birds. For three weeks the broilers were fed at appetite pelleted diets containing $18.4 \%$ protein, made up of $(\%)$; wheat 60.3 ; RSM 35 ; limestone 1.4 ; dicalcium phosphate 1.5; $\mathrm{NaCl} 0.4$; mineral-vitamin premix 1 ; L-lysine 0.3 ; starch or enzyme preparations 0.1 .

The cockerels were weighted once a week, and feed intake was measured. The body weight gain and feed utilization was calculated for each pair of birds.

\section{Chemical analysis}

$\mathrm{N}$ content in RSM, diets and excreta was determined by Kjeldahl method, faecal $\mathrm{N}$ in excreta by Ekman et al. (1949), amino acid content on the amino acid analyser a Beckman Model 6300. NDF and ADF were determined according to Van Soest (1967) on Fibertec M (Tecator) apparatus. 
Statistical analysis

The significance, of the differences among groups were estimated using the Duncans multiple range test.

\section{RESULTS}

After $3 \mathrm{~h}$ of RSM incubation without any additives $23 \%$ of the total $\mathrm{N}$ moved into the solution. The extension of the time of incubation by $10 \mathrm{~h}$ only slightly increased the solubility of $\mathrm{N}$ compounds (Table 1).

Incubation with Bio-feed Pro preparation, containing mainly proteolytic enzymes, already after $3 \mathrm{~h}$ caused an increase in the solubility of nitrogenous substances by $45 \%$, and after $10 \mathrm{~h}$ by $61 \%$, in relation to RSM incubated alone.

TABLE 1

Effect of incubation of RSM with enzyme preparations on the solubility of nitrogenous compounds ( $\mathrm{N}$ found in supernatant as percent of total $\mathrm{N}$ )

\begin{tabular}{lccc}
\hline Enzyme & 3 & Incubation time, h \\
& 3 & 5 & 10 \\
\hline Control & 23.3 & 24.7 & 24.7 \\
Bio-feed Mg & 23.3 & 25.3 & 25.6 \\
Bio-feed Plus & 23.8 & 27.3 & 27.2 \\
Energex & 27.8 & 31.4 & 34.0 \\
Bio-feed Pro & 33.8 & 35.8 & 39.9 \\
\hline
\end{tabular}

TABLE 2

Effect of incubation with enzyme preparations on the NDF and ADF content in RSM, \% DM

\begin{tabular}{lcccc}
\hline \multirow{2}{*}{ Enzyme } & \multicolumn{5}{c}{ Incubation time, $\mathrm{h}$} \\
\cline { 2 - 5 } & $\mathrm{NDF}$ & ADF & NDF & ADF \\
\cline { 2 - 5 } & 30.8 & 22.8 & 31.8 & 20.8 \\
\hline $\begin{array}{c}\text { Control } \\
\%\end{array}$ & 100 & 100 & 100 & 100 \\
Bio-fecd MG & 30.5 & 23.0 & 31.2 & 20.3 \\
$\%$ & 99 & 100 & 100 & 98 \\
Bio-feed Plus & 29.8 & 21.1 & 29.0 & 19.3 \\
$\%$ & 97 & 92 & 93 & 93 \\
Energex & 27.4 & 20.6 & 26.8 & 18.6 \\
$\%$ & 89 & 90 & 86 & 89 \\
\hline
\end{tabular}




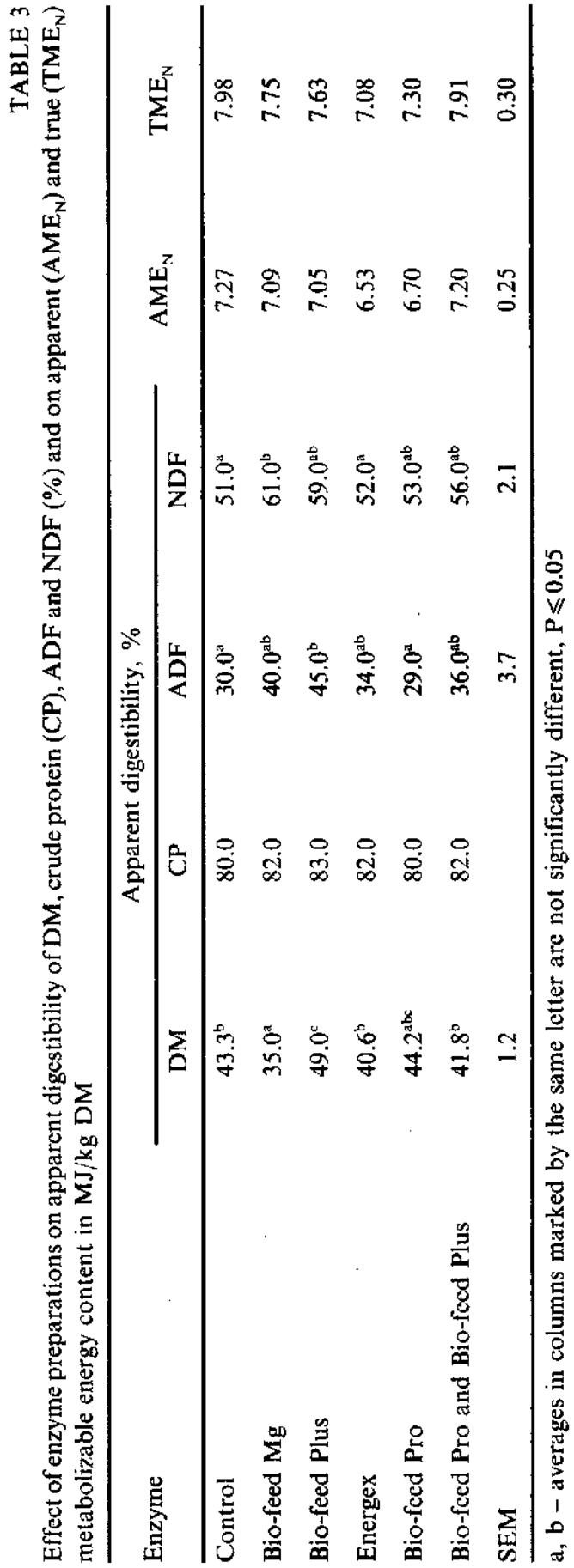




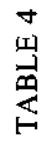

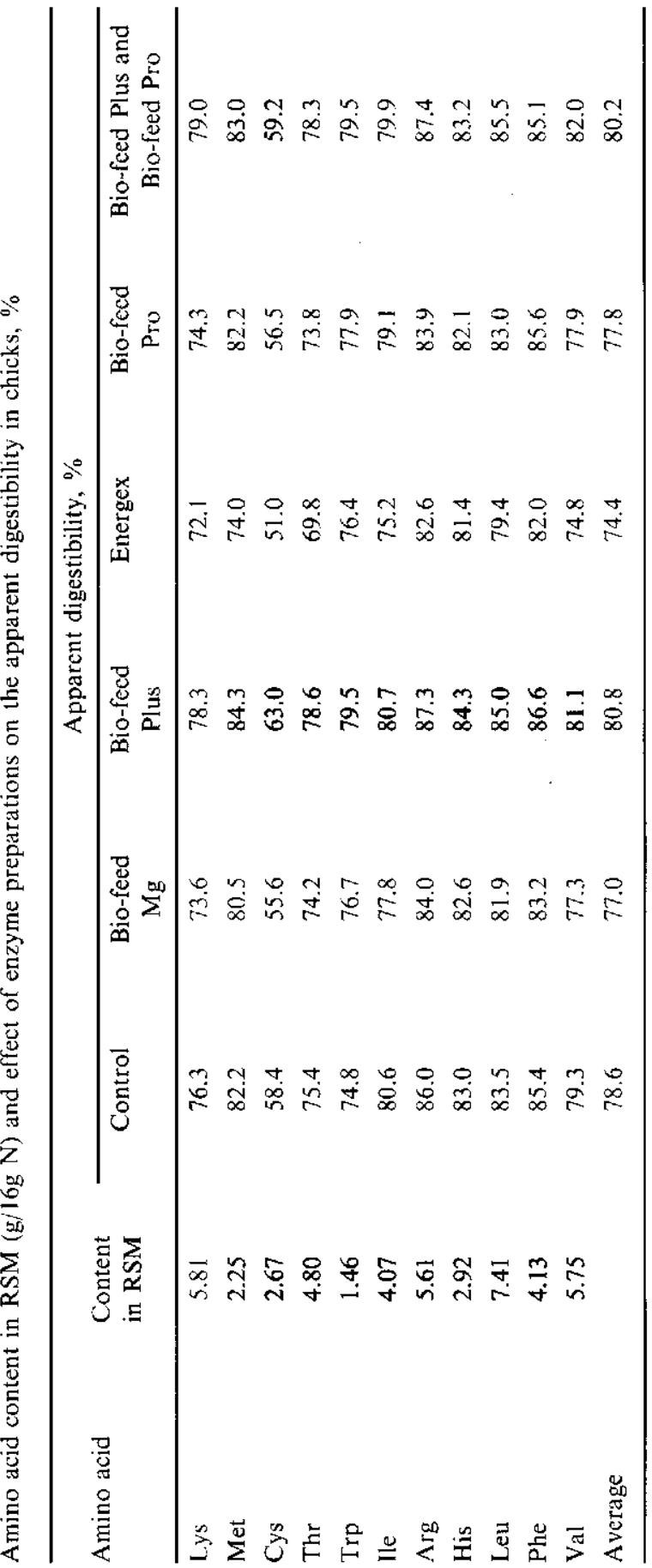


TABLE 5

Effect of enzyme preparations on the feed intake (FI), body weight gain (BWG), and the feed utilization (FU) of broiler chicks between the 7 to 28 days of life

\begin{tabular}{lccc}
\hline Enzyme & FI & BWG & FU \\
\hline Control & $1476^{\mathrm{a}}$ & $702^{\mathrm{a}}$ & $2.11^{\mathrm{ab}}$ \\
Bio-feed Mg & $1435^{\mathrm{a}}$ & $703^{\mathrm{a}}$ & $2.04^{\mathrm{a}}$ \\
Bio-feed Plus & $1446^{\mathrm{a}}$ & $714^{\mathrm{a}}$ & $2.03^{\mathrm{a}}$ \\
Energex & $1401^{\mathrm{a}}$ & $675^{\mathrm{a}}$ & $2.06^{\mathrm{a}}$ \\
Bio-feed Pro & $1489^{\mathrm{a}}$ & $685^{\mathrm{a}}$ & $2.17^{\mathrm{b}}$ \\
Alpha-gal & $1456^{\mathrm{a}}$ & $701^{\mathrm{a}}$ & $2.08^{\mathrm{a}}$ \\
Bio-feed alpha & $1477^{\mathrm{a}}$ & $695^{\mathrm{a}}$ & $2.12^{\mathrm{ab}}$ \\
SEM & 28 & 14 & 0.02 \\
\hline
\end{tabular}

$\mathrm{a}, \mathrm{b}$ - averages in columns marked by the same letter are not significantiy different, $P \leqslant 0.05$

The effect of Bio-fecd $\mathrm{Mg}$ and Bio-feed Plus preparations on $\mathrm{N}$ solubility was negligible. Incubation with Bio-feed $\mathrm{Mg}$ did not cause $\mathrm{ADF}$ and NDF degradation; a $10 \mathrm{~h}$ incubation with Bio-feed Plus caused only a $7 \%$ loss in NDF and ADF content (Table 2).

A $5 \mathrm{~h}$ incubation of the meal with Energex caused a $10 \% \mathrm{ADF}$ and $11 \% \mathrm{NDF}$ degradation, and increased the solubility of $\mathrm{N}$ compounds by $27 \%$. Extension of the incubation time by another $5 \mathrm{~h}$ did not cause a further NDF loss and only slightly increased the $\mathrm{N}$ solubility.

None of the preparations significantly improved the digestibility of DM and protein (Table 3), and amino acids (Table 4), nor the metabolizable energy of RSM (Table 3). Statistically significant increase in NDF digestibility was found in groups receiving Bio-feed $\mathrm{Mg}$, Bio-feed Plus, and Bio-feed Pro preparations statistically significant increase in ADF digestibility in Bio-feed $\mathrm{Mg}$, Bio-feed Plus, and Energex - in relation to control group fed RSM with no additives.

Chicks receiving an unsupplemented diet, containing 35\% RSM, increased their body weight during 3 weeks, by $701 \mathrm{~g}$ on the average, utilizing $2.11 \mathrm{~g}$ feed for $1 \mathrm{~g}$ body weight gain (Table 5). None of the enzymes caused a statistically significant increase in body weight gain of chicks, nor significantly improved the feed utilization. However the best results were observed in the group receiving Bio-feed Plus, the worst in the group receiving Bio-feed Pro.

\section{DISCUSSION}

The comparison of changes in solubility of nitrogenous substances, ADF and NDF of RSM in vitro with changes in protein, NDF and ADF digestibility found in vivo showed that in vitro testing was not a good indicator of the 
effectiveness of enzyme preparations evaluated in the balance experiment and both did not correlate well with growth performance. In vitro, the largest improvement in protein solubility was found after incubation of RSM with Bio-feed Pro and Energex; the largest improvement in fibre solubility after incubation with Energex and Bio-feed Plus. A lowering of the content of non-starchy polysaccharides in RSM after incubation with multi-ingredient enzyme preparation was also noted by Słomiński and Campbell (1990).

In the balance experiment on chicks, Bio-feed Plus addition considerably improved the apparent digestibility of DM, NDF and ADF, but on the other hand Energex did not affect it. However addition of Bio-feed Plus did not cause a better utilization of energy of RSM and the addition of Energex even lowered $A M E_{N}$ of RSM. This may be an evidence that a partial degradation of substances making up NDF or ADF by added enzymes improves their dissolvement but does not lead to the formation of simple sugars that could be absorbed and utilized by the birds.

As Słomiński and Campbell (1990) stressed, the quantity of the compounds determined in RSM as ADF is larger than the amount of cellulose and lignin present. The amount of compounds determined as NDF, on the other hand, fairly well correlated with the total content of non-starchy polysaccharides in RSM. Theander and Åman (1979) showed, however, that in process of NDF evaluation a part of polysaccharides soluble in water was lost.

RSM used in the above experiment was characterized by a high content of crude fibre; its metabolizable energy content determined experimentally was lower $(7.27 \mathrm{MJ} / \mathrm{kg}$ of DM) than calculated according to the WPSA Tables (1986). Nwokolo and Bragg (1978) evidenced that the only components of RSM which can be used by birds as an energy source are fat, starch and simple sugars and that the metabolizable energy of RSM is in poultry negatively correlated with the content of crude fibre $(r=-0.66)$. Also, Chibowska et al. (1993) obtained highly negative correlation $(\mathrm{r}=-0.90)$ between metabolizable energy and content of crude fibre in RSM and its fractions.

Experimentally determined apparent digestibility of RSM protein was slightly higher $(80 \%)$ than that given by the WPSA Tables (1986) - 76\%, the addition of commercial enzymes did not substantially increase protein and amino acid digestibility in RSM.

The influence of added enzymes on the increase in body weight gain of chicks, and on the feed utilization, depended on their composition. Preparations Bio-feed Plus and Bio-feed Mg containing enzymes, whose activity was directed towards solubilizing the dietary fibre of RSM, improved the feed utilization and body weight gain. Addition of Bio-feed Pro and Bio-feed Alpha, on the other hand, caused an increase in feed intake and lowered the body weight gain of the chicks, what resulted in lower feed utilization. Probably the acceleration in 
release of only amino acids (by endoproteinases contained in Bio-feed Pro) or of glucose (by $\alpha$-amylase contained in Bio-feed Alpha) caused a dis- synchronization in their use for anabolic purposes and a larger waste.

It seems that there exists a possibility of improvement of the utilization of RSM by chicks by adding enzymes, although, as Theander and Åman (1977) stressed, multi-ingredient compounds making up dietary fibre of RSM are strongly bounded and difficult to separate into simple elements.

\section{REFERENCES}

Bjergegaard Ch., Eggum B.O., Jensen S.K., Sorensen H., 1991. Dietary fibers in oilseed rape: Physiological and antinutritional effects in rats of isolated IDF and SDF added to a standard diet. J. Anim. Physiol. Anim. Nutr. 66, 69-79

Chibowska M., Pastuszewska B., Smulikowska S., Alloui O. 1993. Chemical and energy value of double-low rapeseed meal fractions for chicken (in Polish). Post. Nauk rol. 6, 167-172

Ekman P., Emanuelson H., Fransson A., 1949. The digestibility of protein in poultry. Kgl. Lantbruks-Hogskol. Ann. 16, 749

European Table of Energy Values for Poultry Feedstuffs, 1986. WPSA, Beekbergen, The Netherlands

Nwokolo E., Bragg D.B., 1978. Factors affecting the metabolizable energy content of rapeseed meals. Poultry Sci. 57, 954-958

Sibbald I.R., 1986. The TME system of feed evaluation: methodology, feed composition data and bibliography. Technical Bulletin, 1986. 4E. Produced by Research Program Service, Agriculture, Canada

Słomiński B.A., Campbell L.D., 1990. Non-starch polysaccharides of Canola meal: quantification, digestibility in poultry and potential benefit of dietary enzyme supplementation. J. Sci. Food Agric. 53, 175-184

Theander O., Aman P., 1977. Fractionation and characterisation of polysaccharides in rapeseed (Brassica napus) meal. Swedish J. Agric. Res. 7, 69-77

Theander O., Aman P., 1979. Studies on dietary fibres. I. Analysis and chemical characterization of water-soluble and water-insoluble dietary fibers. Swedish J. Agric. Res. 9, 97-106

Van Soest P.J., 1967. Use of detergent in the analysis of fibrous feeds. IV. Determination of plant cell-wall constituents. J. Assoc. Off. Agric. Chem. 50, 50-55

\section{STRESZCZENIE}

Whyw preparatów enzymatycznych na trawienie niskoglukozynolanowej śruty rzepakowej in vitro i jej wykorzystanie przez kurczęta brojlery

Zbadano wpływ 6 wieloskładnikowych preparatów enzymatycznych, zawierających enzymy rozkładające węglowodany nieskrobiowe, na wartość odżywczą przemystowej niskoglukozynolanowej śruty rzepakowej (RSM). In vitro RSM z dodatkiem $1 \%$ każdego z preparatów micszano z buforem octanowym $\mathrm{i}$ inkubowano przez 3,5 lub 10 godz. In vivo RSM bez lub z dodatkiem $0.3 \%$ 
każdego $z$ preparatów granulowano i podawano jako jedyną paszę w szybkim doświadczeniu bilansowym na 70, 4-tygodniowych kogutkach brojlerach, oraz diety zawicrające $35 \%$ RSM ber lub $z$ dodatkiem $0.1 \%$ każdego $z$ preparatów podawano przez 3 tygodnie 196 kogutkom brojlerom w wieku 8 dni.

In vitro jedynic Bio-fced Pro i Energex zwiększyły rozpuszczalność białka (odpowiednio o 61 i $27 \%$ po 10 godz), a Energex zwiększyl hydrolizę NDF (o 14\%) i ADF (o $11 \%$ ) po 10 godz. Żaden z preparatów nie polepszył w sposób istotny strawnoścj białka, aminokwasów, ani nic zwiçkszył energii metabolicznej RSM w doświadczeniu bilansowym, chociaż obserwowano istotne zwiększenie pozornej strawności NDF i ADF po dodaniu niektórych preparatów.

Zaden z preparatów nic wplynąl w sposób istotny na wyniki tuczu kurcząt, jednak kogutki żywione dietą $\mathrm{z}$ dodatkiem preparatu Bio-feed Plus były najcięższe i najlepiej wykorzystywały paszę, a kogutki żywione dietą z dodatkiem Bio-feed Pro najgorzej wykorzystywały paszc̨. 